DOI: 10.12731/2658-4034-2020-3-20-23

\title{
ДУХОВНОСТЬ, ТВОРЧЕСТВО И ДУХОВНО-НРАВСТВЕННОЕ ВОСПИТАНИЕ
}

\section{Зотова O.A.}

Ульяновский Государственный Технический Университет, г. Ульяновск, Российская Федерация

Рассматриваются понятия духовность, духовно-нравственное воспитание. Анализируется влияние творчества на духовно-нравственное развитие личности.

Ключевые слова: духовность; духовно-нравственное воспитание; творчество; личность

\section{SPRITUALITY, CREATIVITY \\ AND SPIRITUAL AND MORAL EDUCATION}

Zotova O.A.

Ulyanovsk State Technical University, Ulyanovsk, Russian Federation

The consepts of spirituality, spiritual and moral education are considered. The article analyzes the influence of creativity on the spiritual and moral development on a person.

Keywords: spirituality; spiritual and moral education; creativity; person.

Русская духовность занимает значительное место в содержании жизни русского народа. Она всегда придавала особую окраску русской цивилизации, вызывала и вызывает интерес к себе во всем мире. В создании духовного облика России принимали и принимают участие писатели, композиторы, художники, скульпторы, 
режиссеры, учёные, актеры, т.е. люди творческих профессий. Их деятельность способствует формированию духовного мира личности и относится к одному из средств духовно-нравственного воспитания, рассмотрение которого является целью данного исследования. Ранее опубликованные работы были посвящены анализу понятий «мораль», «нравственность», «духовность».

Методы нашего исследования: анализ и систематизация изученного материала.

Термин «духовность» берёт свое начало от слова «дух».

В философии, этике и культурологии понятие «духовность» не имеет единого толкования.

Так, философы С.Ф. Анисимов, А.Г. Здравомыслов отождествляют духовность с «духовной деятельностью и духовной жизнью», считая, что одним из ее главных элементов является духовное производство», составляющее духовную культуру. Может показаться, что некоторые из областей являются материальными (например: дом, пища, одежда) в то время как другие относятся к духовной сфере. Такое деление условно, так как не существует резкой границы между материальным и духовным в народной культуре, поскольку каждое явление длительно формировалось в сознании народа.

Большой интерес представляет исследование Н.А. Некрасовой. Духовность, по утверждению автора, есть «трансцендентное качество личности», в основе которого лежит способность индивида, во-первых, творить свой внутренний мир, осознавая и сопереживая «полученную информацию», во-вторых, совершенствовать свои добродетели [3, с. 9]. Духовность, по Н.А. Некрасовой, это не только внутренний мир личности, но и её бытиё, основанное на творческой жизнедеятельности человека. Среди функций духовности автор выделяет «смыслообразующую, аксиологическую, целостнообразующую, коммуникативную, интегрирующую, культурообразующую, регулятивную, информационную, познавательную и эвристическую» [Там же, с.19]. Необходимым атрибутом духовности, по убеждению Н.А. Некрасовой, является творчество. Аналогичную точку зрения выражает и исследователь Л.С. Болотова, полагающая, что духов- 
ность - это результат «бескорыстного труда мастера, вкладывающего любовь, тепло души» в свои работы [1].

Мир творчества - одна из важнейших сторон жизни человека, позволяющая созидать красивое и изучать, формировать себя в процессе этой деятельности. Поэтому духовность расцветает не сама по себе, а как творение рук человеческих. По оценке Болотовой, взаимодействие духовных творческих людей при осуществлении совместных проектов не просто увеличивает творческий потенциал, но и повышает эффективность труда.

Исходя из этого, творчество рассматривается как деятельность, создающая новые материалы и духовные ценности, обладающие своей уникальностью и исключительностью замысла автора. Произведения искусства не только вдохновляют нас, но и духовно обогащают. Личность развивается при общении с великими людьми, произведения которых изучает. Сюжеты и образы художественных произведений обобщают жизненные явления и типизируют черты, давая представления о национальном характере народа: духовности, миролюбии, отзывчивости, терпимости, патриотизме и др.

В психологическом обиходе (Е.И. Исаев, В.И. Слободчиков) духовность определятся как потребность в постижении окружающего мира, своего внутреннего «Я» и в осознанном понимании своего назначения в жизни [4, с. 335].

В педагогике духовность рассматривается, во-первых, как «уровень развития и саморегуляции зрелой личности»; во-вторых, как способность конкретного человека к «миро - и самопониманию», стремление жить для других и поиск нравственных идеалов [5, с. 82].

В рассмотрении проблемы духовно-нравственного воспитания существует несколько подходов в её осмыслении.

Так, представители первой точки зрения (И.А. Колесникова, С.И. Маслов) подразделяют его на «воспитание нравственности и восхождение к духовности» [2, с. 21].

Последователи второго подхода (Т.И. Власова, Н.Н. Никитина, Т.И. Петракова, Т.Феоктистова, Н. Шитякова), делают акцент на единстве духовного и нравственного. Авторы трактуют его как «це- 
ленаправленное создание условий для становления духовно-нравственной сферы личности».

Таким образом, духовно-нравственное и творческое развитие личности отражается в системе её экзистенциальных ценностей. Знания о художественных ценностях будут способствовать формированию личности, развивать ее нравственные идеалы, воспитывать культуру чувств и эстетический вкус.

\section{Список литературы}

1. Болотова Л.С. Россия должна жить, как Единая Община [Электронный ресурс] / Л.С. Болотова. 2008. Режим доступа: http://www. APINEWS.RU

2. Зотова О.А. Эволюция идей духовно-нравственного воспитания в педагогике Германии конца XVIII - начала XX вв: дис... канд пед. наук / О.А. Зотова. Ульяновск, 2009. 192 с.

3. Некрасова Н.А. Феномен духовности: бытие и ценность / Н.А. Некрасова: автореф. дис... д-ра философских наук. Иваново, 2002. 35 с.

4. Слободчиков В.И. Психология человека / В.И. Слободчиков, Е.И. Исаев. М.: Школа-Пресс, 1995. 384 с.

5. Словарь по педагогике / Коджаспирова Г.М., Коджаспиров А.Ю. М.: ИКЦ «МарТ»; Ростов н/Д: «МарТ», 2005. 448 с.

\section{References}

1. Bolotova L.S. Rossiya dolzhna zhit', kak Edinaya Obshchina [Elektronnyy resurs] / L.S. Bolotova. 2008. - Rezhim dostupa: http://www.APINEWS.RU

2. Zotova O.A. Evolyutsiya idey dukhovno-nravstvennogo vospitaniya $v$ pedagogike Germanii kontsa XVIII - nachala XXvv: dis... kand ped. nauk / O.A. Zotova. Ul'yanovsk, 2009. 192 s.

3. Nekrasova N.A. Fenomen dukhovnosti: bytie i tsennost' / N. A.Nekrasova: avtoref. dis... d-ra filosofskikh nauk. Ivanovo, 2002. $35 \mathrm{~s}$.

4. Slobodchikov V.I. Psikhologiya cheloveka / V.I. Slobodchikov, E.I. Isaev. M.: Shkola-Press, 1995. $384 \mathrm{~s}$.

5. Slovar' po pedagogike / Kodzhaspirova G.M., Kodzhaspirov A.Yu. M.: IKTs «MarT»; Rostov n/D: «MarT», 2005. 448 s. 